\title{
Transfer Of Criminal Activities From One Country To Other
}

\section{Desy Kartika C Sitepu}

Sumatera University Faculty Of Law. E-mail: desysitepu12@gmail.com

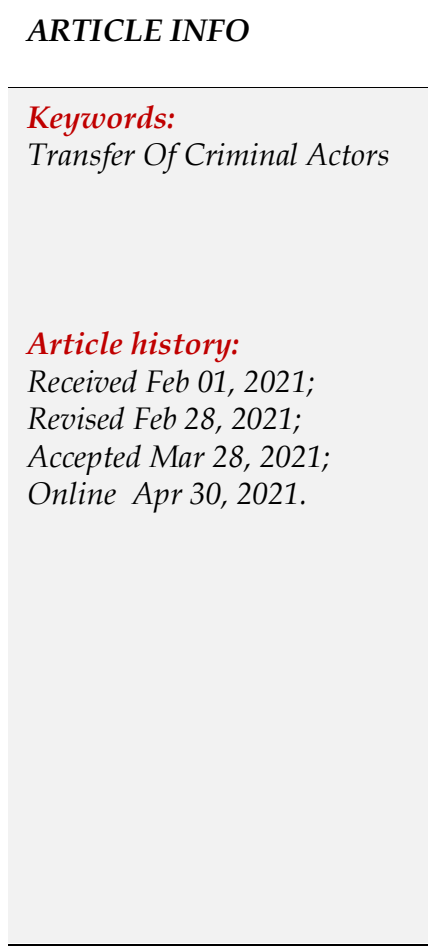

\begin{abstract}
Extradition is defined as the surrender of criminals from one country to another. The purpose and objective of extradition is to ensure that the perpetrators of serious crimes cannot escape prosecution or punishment. Therefore, it is appropriate and appropriate for the criminal to be handed over for examination and trial by a state having jurisdiction. The issue raised is the extradition procedure according to Law Number 1 of 1979, the types of crimes that can be requested for the transfer of the perpetrators of criminal acts. The method used is a normative juridical approach, namely research based on literature study. The literature study was conducted to find secondary data, while secondary data were primary legal materials in the form of criminal law literature, extradition and other secondary legal materials. Meanwhile, the tertiary legal materials used in this paper are materials obtained from the internet. Extradition procedures according to Law Number 1 of 1979 are conditions that must be carried out in the process of transferring criminals from one country to another. The perpetrator of a criminal act who can be extradited is any person whom the competent authority from a foreign country requests from Indonesia, on the basis that the person concerned is suspected of committing a crime in order to be able to serve a sentence, while a crime that cannot be extradited is a political crime.
\end{abstract}

This is an open access article under the CC BY-NC license.

\section{Introduction}

The state exists for the sake of humans, therefore, the state must strive to achieve happiness for every human being (its citizens)1. Thus, the state provides happiness and welfare to its citizens. This happiness and welfare can be achieved only through law, because law can create order, justice, and peace of life which then creates a prosperous, just, and prosperous society (citizen) life. In this regard, Van Hattum stated that. Every country is obliged to guarantee security and order within the territory of their respective countries, therefore judges from each country can try every person within the territory of their respective countries who has committed a crime, by enacting the Criminal Law applicable in his country. that the Criminal Law of a country can not only be applied to citizens of that country, but also to any foreigner who is known to have committed a crime within the territory of his country.

The request for the transfer of the perpetrator of a crime can be made for perpetrators of criminal acts with the status of suspects and convicts, where the perpetrators of criminal acts with the status of suspects are criminals who are still undergoing the judicial process or examination, while the perpetrators of criminal acts with the status of prisoners (convicts) are perpetrators of criminal acts. a criminal sentence that has been sentenced with permanent legal force. 
The issue of extradition, which is defined as the handing over of criminals from one country to another, in Indonesia today is increasingly popular and is starting to become popular in the community. This is partly due to:

a. There have been cases of extradition involving Indonesia, especially between 1965 and now, such as the Tan Hoa case in 1968, the Mimi ship case in 1975 and many other cases.

b. Indonesia has entered into extradition agreements, including agreements between Indonesia and the Philippines, agreements between Indonesia and Malaysia and explorations to other neighboring countries.

c. Reports from the press and other mass media helped to popularize the term and meaning of extradition

d. Especially among legal experts, the issue of extradition is closely related to national and international law, so like it or not, they also want to learn about the extradition. Moreover, in the context of the formation of a national extradition law.

After the life of the state has begun to appear somewhat more advanced, especially from the 17th, 18th, 19th centuries to the twentieth century, with the growth of national states, international relations and relations have begun to seek and find new forms, States in making treaties- The treaty has begun to specialize in certain fields of legal instruments in the form of an international agreement which regulates the issue of criminal acts whose status as suspects is the Extradition Institution, which is an international agreement between two countries in accordance with the criminal acts contained in the agreement.Extradition as a legal institution that is quite old, now there is no need to doubt its existence either as part of international law in general or as part of international criminal law in particular, even as part of international law, extradition appears in the forms of international treaties. bilateral or multilateral-regional, while as part of the national law of extradition, it appears in the form of national laws and regulations of countries regarding extradition3.Extradition appears in the forms of bilateral or multilateral-regional international agreements, while as part of the national law, extradition appears in the form of states' national laws and regulations regarding extradition3.Extradition appears in the forms of bilateral or multilateral-regional international agreements, while as part of the national law, extradition appears in the form of states' national laws and regulations regarding extradition.

Extradition is a bridge that can connect two or more countries in dealing with criminals involving the interests of two or more countries. Especially for Indonesia, whose territory is located at the crossroads of international traffic, is an easy nest for perpetrators of criminal acts such as smuggling, illicit human and labor trafficking, terrorism and others. one of the most pressing needs. Likewise, legal experts should also understand about extradition because extradition is partly national law, especially closely related to criminal law.

\section{Method}

The type of research used is normative legal research, namely research conducted on legal principles, research on legal systematics, research on the level of legal synchronization and research on legal history. This research was conducted by examining library materials that are relevant to the problem being studied. Normative juridical research sees law in a normative sense (law in the book).

Research Library (Library Studies), namely studying and systematically analyzing books, laws and regulations, lecture notes and other literature sources related to the material discussed in this thesis in order to obtain scientific data as material in the theoretical description.

Data Analysis, Data analysis in this paper uses qualitative data, which is a clear data analysis and described in the form of sentences so that a clear picture is obtained related to this thesis. 


\section{Analysis And Results}

\subsection{Types Of Crime That Can Be Permitted Exradiction Request}

\section{a. Types Of Crimes That Can Be Carried Out by Transferring The Perpetratos Of Criminal Acts (Extradition)}

The development of the quality of criminal acts or crimes shows that the territorial boundaries between one country and another in the world, both within one region and in different regions, have increasingly disappeared. Nowadays, it is almost certain that all types or forms of crime cannot only be viewed as criminal jurisdictions of more than one country or two countries, giving rise to jurisdictional conflicts that greatly disrupt international relations between countries with an interest in certain criminal cases that are transnational in nature. territorial boundaries.

The international community recognizes that the development of criminal acts across territorial borders has further heightened the level of difficulty of cooperation between countries in preventing and eradicating crime, especially if foreign nationals are involved in the crime.

1) Based on the Transfer of Sentenced Persons Agreement

As a form of international agreement that is multilateral and open, in the field of criminal law, the Transfer of Sentenced Persons agreement has now occupied a fairly honorable place. This is evident from the legal forms that govern it, both in the form of bilateral, regional and multilateral international agreements, as well as in the form of national legislation of countries. The Transfer of Sentenced Persons Agreement specializes in the field of criminal law, related to the transfer of convicts (sentenced persons) from the country where the convict is in law (sentencing state) to the convict's country of origin (administering state) using international agreements. Arrangements for the Transfer Of Sentenced Persons agreement are regulated in a convention, namely the Convention On The Transfer Of Sentenced Persons, which was ratified on March 21 in Strasbourg.Based on its form, the Transfer of Sentenced Persons agreement is a written international agreement. In accordance with the times, international agreements and International Transfer of Sentenced Persons relations must be in written form, including agreements. This is because international agreements in written form have several advantages, such as firmness, clarity, and guarantees legal certainty for the the promised party, where the results of the agreement of the parties are stated in the form of a written document.47 The Transfer of Sentenced Persons agreement made by the official organ of a country that made the agreement will be binding on the country.

If we examine and thoroughly trace the articles of the Transfer Of Sentenced Persons agreement, explicitly (firmly) there is no single article that mentions the types of crimes that can be transferred. Unlike the extradition treaty which explicitly states the types of crimes that can be transferred through extradition in principle, the types of crimes referred to in the Transfer of Sentenced Persons agreement are international crimes, namely in the form of war crimes (war crimes), genocide (crimes of eradicating certain ethnicities), aggression or aggression, and others. Actions or actions that meet the requirements as a violation of the public interest, nations or the international community and fulfills the requirement that the crime in question requires international handling so that international response to the crime in question has the right and obligation and obligation to arrest, detain and prosecute, as well as prosecute the perpetrators of the said crime wherever the crime is committed. it's done48. These international crimes are regulated in the provisions of international criminal law, namely the principles or principles of criminal law that indicate the existence of truly international crimes. and prosecute the perpetrators of the said crimes wherever the crimes were committed 48 . These international crimes are regulated in the provisions of 
international criminal law, namely the principles or principles of criminal law that indicate the existence of truly international crimes. and prosecute the perpetrators of the said crimes wherever the crimes were committed48. These international crimes are regulated in the provisions of international criminal law, namely the principles or principles of criminal law that indicate the existence of truly international crimes.

2) Under Extradition Institution Arrangements

Extradition can be interpreted as a formal surrender, either based on a pre-existing extradition agreement or based on the principle of reciprocity or reciprocity, of a person accused of committing a crime or someone who has been sentenced to a criminal sentence that already has a criminal sentence that has binding force. (convicted, convicted), by the country where he is (the requested country) to the country that has jurisdiction to try or punish him (the requesting country), at the request of the requesting country, with the aim of trying and or implementing the sentence. In Article 3 paragraph 1 of Law Number 1 of 1979 it is emphasized that: about who can be extradited or requested for extradition. Those who can be extradited are any person who is requested by the competent authority from a foreign country to Indonesia, on the basis that the person concerned is suspected of having committed a crime in order to be able to serve a sentence or a detention order.

Based on the principle of double crime or double criminality, the crime that is suspected to have been committed or the criminal sentence that has been imposed must be a crime both according to the law of the requesting country and the law of the requested country. This principle reflects that the act of the person requested is not justified according to the national criminal law of the two countries which also means that the act is a crime according to the legal awareness and sense of justice of the people of the two countries and therefore the perpetrator must be tried and also proven guilty must be sentenced. worth it. Extradition is carried out for the crimes mentioned in the list of crimes attached as an integral part of this law. In the attachment, it is detailed as many as 32 types of crimes that can be used as the basis for requesting extradition.

\section{b. Types of Crimes That Can't Be Transferred}

Definitive definition of crime is not found uniformity of opinion. Scholars express their own opinions.According to GW Bawengan, crime is a name or stamp given by people to judge certain actions as evil. According to him, the notion of crime comes from the realm of values, so crime has a very relative meaning, which is very dependent on humans who give judgments. So, what someone calls a criminal does not always have to be recognized by the other party as a criminal as well. For example: all groups can accept that a certain act is a crime, then the severity of the act still causes differences of opinion.

According to R. Soesilo distinguishes the juridical understanding of crime and the sociological understanding of crime. From a juridical point of view, the definition of crime is an act of behavior that is contrary to the law. The law must be created first before a criminal event occurs in order to see whether the act is contrary to the law. This is not only to prevent arbitrary actions from the authorities but also to provide legal certainty. From a sociological perspective, what is meant by crime is an act or behavior that in addition to harming the sufferer is also detrimental to society, namely in the form of loss of balance, peace and order.

1) Definition of Political Crime

Limitations or definitions of political offenses are not found in Indonesian legislation58. Except, the term political offense contained in Law No. 1 of 1979 concerning Extradition, which in article 5 of the Law states that political crimes cannot be extradited. Politics is closely related to the achievement of a goal.59 Politics is a 
process that exists within a group of people, certain groups or individuals to achieve certain goals. Political crime is if the basis of the act committed is for political purposes. Often political crimes are carried out openly, namely through ordinary (complex) crimes, such as murder, destruction of goods. Or sometimes it is also carried out in conjunction with ordinary crimes (by connex), for example the theft of weapons64. In both cases, political crimes are objective, subjectively a political crime cannot be determined based on its political motives. Political offenses are the most atypical offenses, because the perpetrators with full awareness believe in good faith, have done something according to their beliefs that do not conflict with the order of society, even if their actions are for the good of society and justice, even though their actions may be followed by acts of violence.

2) Crimes that are not expressly classified as political crimes.

Because of the difficulty in determining the criteria for political crimes, nowadays there is a tendency to further limit the scope of political crimes. There are types of crimes that are expressly declared as non-political crimes, namely: murder crimes, attempted murder or attempted murder of the head of state, government or family members which have generally been accepted as non-political crimes which are better known as attentat clauses (Clausula attenta is a a provision regarding one type of crime which, although clearly it can be classified as a political crime or in other words its political nature is abolished, is a crime that eliminates or attempts to eliminate the life of the head of state and/or his family members).

3) Political Crime Cannot Be Transferred

Regarding political crimes, it is recognized that the definitions of these crimes can be very broad and there is no uniformity about the content and scope of political crimes between different countries69. The determination of whether a crime is a political crime or not is left to each country. Regarding the surrender of citizens, this is based on the consideration that between the state and its citizens there is a close relationship where the state is the best shelter for its citizens. However, what, What is meant by political crimes at the beginning of its development is only crimes against the legitimate government or those in power. Where the perpetrator has political beliefs that are different from the government in power. The inability to request the transfer of perpetrators of political crimes is a specialty of political crimes. This specificity is regulated or determined in the Transfer of Senteced Persons agreement and also in the extradition agreement. In the Transfer of Senteced Persons agreement, it is not possible to transfer the perpetrators of political crimes, it is determined that the condition for the transfer of the perpetrators of the crime is a crime that is not a crime. in the law, one of which is the principle of not surrendering the perpetrators of political crimes (Non Extradition Of Political Criminal). And more specifically, this principle is regulated in Article 5 of the National Extradition Law on political crimes, which states: Article 5:

a) Extradition is not carried out for political crimes

b) Crimes which are essentially more ordinary crimes than political crimes are not considered political crimes.

c) For certain political crimes, the perpetrators can also be extradited as long as it is agreed between the Republic of Indonesia and the State concerned.

From this provision it can be interpreted that, the requested state must refuse surrender the requested person if according to the requested country, the crime that is used as a reason for requesting the surrender or transfer is a political crime. With this refusal, the requested person gets protection from the requested state, therefore the requested state also cannot try the requested person himself. Regarding the transfer of perpetrators of criminal acts, whether 
through Transfer of Sentenced Persons agreements or extradition institutions, cannot be separated from a person's human rights, in relation to the right to legal protection, the right to equality before the law, the right to an effective trial by national courts that authority, the right not to be deprived of independence and so on. With regard to human rights, it affects the implementation of the transfer or surrender of perpetrators of criminal acts, including those of political crimes.

In political crimes, the refusal to hand over the perpetrators of political crimes is based on the obligation of all parties to respect human rights. namely, that everyone has the right to his political views and beliefs each of them, even though they are different, even contradict the political beliefs of others, even with the political views held and applied by those in power. Or in other words, the perpetrators of political crimes cannot be transferred or handed over in relation to the right of the state to grant political asylum to political fugitives.

Besides that, there are practical considerations to hand over the perpetrators of political crimes even though they are still related to human rights. Even though the perpetrators of political crimes are at the time of resisting the legal authorities in a formal juridical manner, he commits a crime, but maybe at some point in time. the ruler he opposed turns out to be no longer in power and there is a possibility that the ruler fell because he was overthrown by his political opponents. Or very possibly, the ruler who fell or was overthrown was considered a criminal and deserved to be tried and sentenced.

If the perpetrator of the political crime is handed over to the ruler (before falling and being overthrown) then his fate will depend on the temporary ruling authority, where the ruler himself in the future is uncertain about his fate. On the other hand, if the ruler he opposes falls or is overthrown, then if he returns to his country, he may become the leader and ruler of his country, which will determine the fate of the fallen ruler. Therefore, it is considered more just and wise if the perpetrators of political crimes are not handed over so that one's fate does not depend on the hands of other people (rulers) whose fate is uncertain in the future. The exception to the crime that can be handed over or transferred to a political crime actor from the requested country to the requesting country is in the event of a murder or attempted murder of the head of state or his family members72. Because the act is not considered a political crime, even though such a thing may happen with a political background or purpose.

\section{Conclusion}

The extradition procedure according to Law Number 1 of 1979 includes, among other things, the conditions for detaining the person requested based on a request from the requesting country, namely what conditions must be met by the requesting country so that the person requested can be detained, the conditions for a request for extradition to can be considered, regarding the examination of the extradited person, the revocation and extension of detention, the decision regarding the request for extradition, namely whether the request for extradition will be granted or rejected and regarding the surrender of the requested person, evidence and others. Indonesia supports the extradition process of criminals through its national law.

The types of crimes that can be used as a basis or reason for requesting extradition are listed in a list containing the types of crimes that can be extradited. Where these crimes must meet the principle of double crime. In the attachment of Law Number 1 of 1979 concerning extradition, there are 32 types of crimes that can be extradited, wherein the attachment is a text that cannot be separated from the law, so it is clear that in the extradition treaty it is expressly stated which crimes can be extradited. Political crimes are crimes that cannot be extradited based on the obligation of all parties to respect human rights. 


\section{References}

Bawengan, GW, Introduction to Criminal Psychology, Pradnya Paramita, Jakarta, 1991.

Budiarto, M, Problem Extradition and guarantee protection on rights basicman .(book 1), Jakarta: Ghalia,1980

Extradition in National Law (book 2). Jakarta: Ghalia, 1981.

Chazawi, Adami, Material Criminal Law and Formal Corruption in Indonesia (book 1). Bayumedia, Malang ,2005.

, Criminal Law Lessons Part II (book 2), Jakarta : Raja Grafindo Persada, 2002,

Damian, Eddy, Kapita Selekta International Law, Bandung: Alumni, 1991, Hartanti, Evi, Corruption Crimes, Sinar Graphic, Semarang, 2005.

Loqman, Loebby, Political Offenses in Indonesia, publisher IND-HILL-CO, Jakarta, 1993. Parthiana, I Wayan, Extradition in Modern International Law, (Book 1) Yrama Publisher Widya, Bandung, 2009.

Extradition in International Law and Indonesian National Law (Book 2), CV Mandar Maju, Bandung, 1990.

, Extradition in International Law and National Law (book 3), Alumni, Bandung, 1983.

International Criminal Law and Extradition (book 4), Yrama widya, Bandung, 2003

Ridwan, HM, Ediwarman, Principles of Criminology, USU Press, Medan, 1994.

Starke, JG Introduction to International Law Tenth Edition, Sinar Graphic, Jakarta, 2007 Syahmin, AK, International Treaty Law, In the framework of analytical studies (book 1),

Publisher PT Raja Grafindo Persada, Jakarta, 2006.

Public International Law, Within the Framework of Analytical Studies, (book 2), Bina Cipta, Bandung, 1992.

Sianturi, SR, Principles of Indonesian Criminal Law and Its Application, Ahaem Petehaem Alumni, Jakarta, 1996.

Situni, Whisnu, Identification and Formulation of International Legal Resources. CV Mandar Maju, Bandung, 1989.

Soekanto, Soerjono, Normative Legal Research: a Brief Overview, Rajawali Press, Jakarta, 2001.

Law Number 1 of 1979 concerning the Extradition of the Criminal Code Criminal Procedure Code.

Extradition, accessed from the sitehttp://www.interpol.go.id Unpad. AC ID/wp-contect/International treaties.pdf.

Akrial, Zul. The principle of not surrendering one's own nationality is associated with politics, national law, accessed from the sitewww. Legalitas.org.

http:/ /law .Unsrat.ac.id.

Romli Atmasasmita, the legal policy of cooperation in the field of extradition in the era of globalization, is accessed from the website:http://www.legalitas.org.

http://www.zimbio.com 